\title{
Multiplex PCR approach to simultaneously identify several mutations in fine needle cytology thyroid samples
}

\author{
Emilia Vuttariello, Marco Borra², Elvira Mauriello², Celeste Calise ${ }^{3}$, Barbara \\ $D^{\prime}$ Andrea ${ }^{2,3}$, Anna Capiluongo ${ }^{1}$, Franco Fulciniti ${ }^{4}$, Anna Cipolletta ${ }^{5}$, Mario Monaco ${ }^{1}$, \\ Luciano Pezzullo ${ }^{6}$ and Gennaro Chiappetta ${ }^{1}$ \\ ${ }^{1}$ Functional Genomics Unit, Istituto Nazionale Tumori, IRCCS, Fondazione G. Pascale, Naples, Italy \\ ${ }^{2}$ Molecular Biology and Bioinformatics Unit, Stazione Zoologica "A.Dorhn", Naples, Italy \\ ${ }^{3} \mathrm{CMO}$, Naples, Italy \\ ${ }^{4}$ Clinical Cytopathology Service, Institute of Pathology, Locarno, Switzerland \\ ${ }^{5}$ SC Anatomia Patologica e Citopatologia, Istituto Nazionale Tumori, IRCCS, Fondazione G. Pascale, Naples, Italy \\ ${ }^{6}$ Thyroid Surgery Unit, Istituto Nazionale Tumori, IRCCS, Fondazione G. Pascale, Naples, Italy \\ Correspondence to: Emilia Vuttariello, email: e.vuttariello@istitutotumori.na.it \\ Gennaro Chiappetta, email: chiappettagennaro@gmail.com
}

Keywords: multiplex PCR, thyroid, fine needle cytology, genetic testing, Sanger sequencing

Received: November 24, 2016

Accepted: April 19, 2017

Published: May 07, 2017

Copyright: Vuttariello et al. This is an open-access article distributed under the terms of the Creative Commons Attribution License 3.0 (CC BY 3.0), which permits unrestricted use, distribution, and reproduction in any medium, provided the original author and source are credited.

\section{ABSTRACT}

The most frequent initial manifestation of thyroid cancer is the appearance of a nodule. More than $\mathbf{2 0} \%$ of the general population has a palpable thyroid nodule and the percentage rises to $70 \%$ based on ultrasound identification. In $95 \%$ of cases the nodule is simply a hyperplastic or benign lesion. The most reliable diagnostic test for thyroid nodules is fine needle aspiration (FNA), but cytological discrimination between malignant and benign follicular neoplasms remains difficult. Cytological analysis is now, almost routinely, being combined with molecular genetics to enable the pathologist to make a more objective diagnosis. In this study, we performed the molecular analysis using a new simplified procedure that involves a panel of BRAF, RAS, RET and RET/PTC gene mutations in easily obtainable FNA samples, in the attempt to improve the efficacy of the FNA diagnosis of thyroid nodules and thus patient management. In this new procedure, PCR and sequencing analysis are used to detect point mutations, and, in parallel, RT-PCR is used to detect the chimeric RET/PTC1 and RET/PTC3 transcripts in RNA extracted from FNA.

\section{INTRODUCTION}

Thyroid cancer is the most common malignant tumor of the endocrine system [1]. Most thyroid cancers derive from thyroid follicular cells that give rise to well-differentiated papillary (PTC) and follicular (FTC) carcinomas, and undifferentiated forms such as anaplastic carcinoma (ATC) [2], while medullary thyroid carcinomas (MTC) derive from thyroid parafollicular cells or $\mathrm{C}$ cells. Medullary thyroid carcinoma accounts for approximately $5-10 \%$ of all thyroid cancers, $75 \%$ are sporadic and $25 \%$ hereditary. A nodule is usually the initial manifestation of thyroid cancers but in $95 \%$ of cases it is simply a hyperplasic or benign lesion. Therefore, given the low mortality rate of thyroid cancer and the low percentage of malignant thyroid nodules, an accurate diagnosis of lesions will spare patients unnecessary surgery.

Although thyroid nodules are mostly diagnosed by fine needle aspiration (FNA), the cytological discrimination between malignant and benign follicular neoplasms remains difficult despite their distinctive cytomorphological features, PTC, MTC and ATC are easily diagnosed. However, FNA may yield insufficient material or a low number of tumor cells, and many thyroid FNAs are "indeterminate". In the latter case, FNA sampling is usually repeated or in some cases, surgery is performed in the attempt to establish a diagnosis. These procedures result in additional morbidity and higher health 
care costs. Moreover, patients with malignant tumors and indeterminate FNA cytology typically undergo limited surgery, i.e. lobectomy, and once malignancy is established by pathological examination of the excised nodule, these patients must undergo a second operation to complete the thyroidectomy, which also results in additional morbidity and costs. Moreover, $1-3 \%$ of nodules diagnosed as benign on FNAs are later found to be malignant on followup [3]; the consequent delay in treatment places patients at risk of disease progression.

Molecular testing of FNA samples significantly improves the accuracy of the cytological diagnosis of thyroid nodules. Therefore, procedures to improve the sensitivity and specificity of FNA diagnosis could have a significant impact on clinical care [4-6].

A number of genetic mutations are associated with thyroid cancer. The most common genetic mutations in PTC are point mutations involving the $B R A F$ and $R A S$ genes, while the most common chromosomal rearrangement is $R E T / P T C$, which is involved in the mitogen-activated protein kinase (MAPK) pathway [7-9]. These mutations are found in more than $70 \%$ of PTCs, and are mutually exclusive [10-12]. RAS mutations or the $P A X 8 / P P A R \gamma$ rearrangement, which are mutually exclusive, occur in about $80 \%$ of FTCs [13]. Medullary thyroid carcinomas frequently feature point mutations in the RET gene (both hereditary and sporadic). In fact, MTC is transmitted in an autosomal-dominant pattern [14] in multiple endocrine neoplasia (MEN) syndrome (MEN 2A and MEN 2B) and in familial medullary thyroid carcinoma (FMTC). Genetic screening should be performed even in apparently sporadic cases, because about $5 \%$ of sporadic cases of MTC are hereditary [15]. Many other genetic alterations, namely, PIK3CA, PTEN, b-Catenin (CTNNB1), TP53, $A K T$, and $T R K$ rearrangements are involved in thyroid cancer but are rare.

According to the American Thyroid Association guidelines [16], molecular markers such as $B R A F$, $R A S$ and $R E T / P T C$ may be used to type patients with indeterminate FNA cytology and thus help guide management. The classical methods used to detect mutations in these more informative genes involve the use of individual amplifications of exon 15 of $B R A F$, exons 2 and 3 of $H-K-N R A S$ and RET/PTC 1 and RET/PTC3 rearrangement, each analyzed at a different annealing temperature followed by forward and reverse sequencing. We have developed two multiplex PCR assays that enable the simultaneous identification of 15 point mutations. The first PCR assay involves the use of primers to amplify the most important exons of the RET gene. The second consists in the amplification of the $B R A F, H-K$ and $N R A S$ gene mutated regions.

\section{RESULTS AND DISCUSSION}

We developed an efficient and inexpensive method of nucleic acids extraction that yields sufficient material to amplify simultaneously a gene panel to characterize thyroid tissue using separate DNA and RNA extraction kits. A kit is also available for the simultaneous extraction of nucleic acids. The nucleic acid concentrations differed greatly: an average of $22 \mathrm{ng} / \mu \mathrm{l}$ (total $4400 \mathrm{ng} / \mu \mathrm{l}$ ) in the case of DNA, and an average of $61 \mathrm{ng} / \mu \mathrm{l}$ (total $3660 \mathrm{ng} / \mu \mathrm{l}$ ) in the case of RNA, depending on the type of sample, and also on the different characteristics of the nodule such as the presence of calcifications or necrosis that makes the really poor material. It should be noted that we also successfully amplified samples whose absorbance was not readable. We initially used oligos able to anneal at $60^{\circ} \mathrm{C}$ to amplify the desired fragments. We then optimized $\mathrm{MgCl} 2$ concentrations, TAQ polymerase, the oligos/nucleic acid ratio, and the time and cycle number of the amplification step. Figure 1A and 1B show seven different amplification fragments in the $R A S$ $R A F$ multiplex and eight distinct bands in the RET gene multiplex.

Table 1 shows the results obtained with 15 samples classified according to the "Italian thyroid cytology classification system" [17]. We identified 16 point mutations
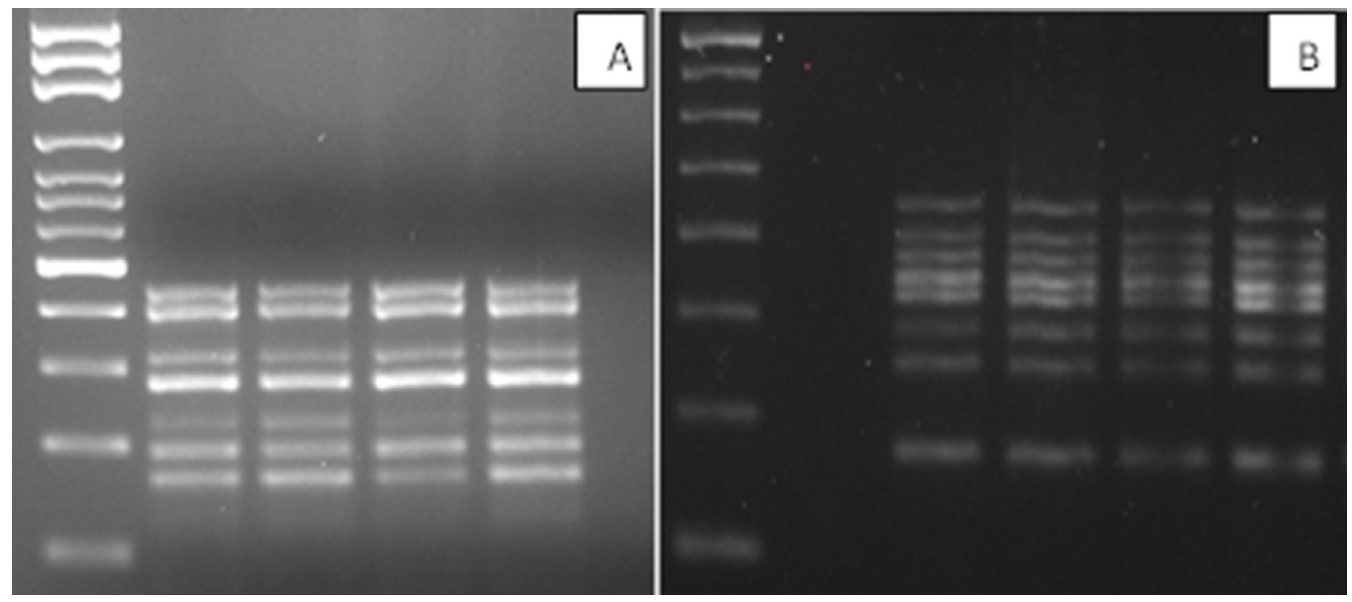

Figure 1: (A) BRAF-RAS multiplex amplification gel (B) RET multiplex amplification gel (2\% agarose gel in 1X TBE). 


\begin{tabular}{|c|c|c|c|c|c|c|}
\hline & BRAF & $\begin{array}{l}\text { NRAS } \\
\text { exon3 }\end{array}$ & & & RET & \\
\hline SAMPLES & & & $\begin{array}{c}\text { ex } 11 \\
\text { mut691 }\end{array}$ & $\begin{array}{c}\text { ex } 11 \\
\text { mut769 }\end{array}$ & $\begin{array}{c}\text { ex } 14 \\
\text { mut836 }\end{array}$ & $\begin{array}{c}\text { ex } 15 \\
\text { mut904 }\end{array}$ \\
\hline TIR2 (2) & & & 1 & & & \\
\hline TIR3 (5) & & 1 & 1 & 1 & 1 & \\
\hline TIR4 (4) & 2 & 1 & & & & \\
\hline TIR5 (3) & 1 & 1 & 1 & 1 & & \\
\hline OTHER (1) & 1 & & 1 & 1 & & 1 \\
\hline Total 15 & $4 / 15(27 \%)$ & $3 / 15(20 \%)$ & & & $9 / 15(60 \%)$ & \\
\hline Mutations/ Samples & & & & $16 / 15$ & & \\
\hline
\end{tabular}

on 15 samples (one sample contained two mutations). Although the number of samples is not sufficient for statistical validation of the results, it does enable us to verify the performance of our method. We are now collecting more cytological samples to evaluate the diagnostic accuracy of the procedure. We also used FFPE DNA and thanks to the use of a 96-well plate (Figure 2) it was possible to automatically analyze five different samples simultaneously. Consequently, the assay is faster and less expensive than those currently used. Also RET/PTC1 and RET/PTC3 amplification was optimized to the $60^{\circ}$ annealing temperature, but neither the RET/PTC1 nor the RET/PTC3 rearrangement was detected in our samples. Due to the concomitant amplification of gene fragments at the same annealing temperature, the procedure is both rapid and practicable.

Fine needle cytology combined with molecular genetics is now the most reliable procedure for the preoperative diagnosis of differentiated thyroid carcinoma [18]. In fact, molecular analysis can provide additional information in multiple histologic variants of welldifferentiated PTC. An example is the follicular variant of PTC (FVPTC), which although being a well-defined histopathological entity, its diagnosis on FNA is usually missed. Recently, a new classification of Encapsulated Follicular Variant Papillary Thyroid Carcinoma (eFVPTC) without capsular or vascular invasion in noninvasive

\begin{tabular}{|c|c|c|c|c|c|c|c|c|c|c|c|c|}
\hline A & Kras ex 2 & RET ex 5 & Wra ex 2 & RET $\operatorname{ex} 5$ & Nas ex 2 & RET ex 5 & Wras ex 2 & RET ex 5 & Wast ex 2 & RET ex 5 & $\begin{array}{l}\text { negative } \\
\text { was ex } 2\end{array}$ & $\begin{array}{l}\text { negarve } \\
\text { RET ex } 5\end{array}$ \\
\hline B & Nras ex 3 & RET ex 8 & Nras ex 3 & RET ex 8 & Kras ex 3 & RET ex 8 & Wras ex 3 & RET ex 8 & Noas ex 3 & RET ex 8 & $\begin{array}{l}\text { negarve } \\
\text { Wras ex } 3\end{array}$ & $\begin{array}{l}\text { negarve } \\
\text { RET ex } 8\end{array}$ \\
\hline C & $\mathrm{Nr} 3 \mathrm{se} 2$ & RET Ex 10 & Nras ex 2 & REt ex 10 & $\mathrm{Nr} 35$ ex 2 & RET EX 10 & Nras ex 2 & RET ex 10 & Nras ex 2 & RET ex 10 & $\begin{array}{l}\text { negasve } \\
\text { Nras ex } 2\end{array}$ & $\begin{array}{l}\text { กะgasve } \\
\text { RET ex } 10\end{array}$ \\
\hline D & $\mathrm{Nr} 3 \mathrm{e} e \mathrm{~s}$ & RET ex 11 & $\mathrm{Nr} 36 \mathrm{er} 3$ & RET ex 11 & Nras exs & RET ex 11 & Nras exs & RET ex 11 & Nras ex3 & RET ex 11 & $\begin{array}{l}\text { negatve } \\
\text { Nras ex3 }\end{array}$ & $\begin{array}{l}\text { Negasve } \\
\text { RET ex } 11\end{array}$ \\
\hline$E$ & Hrasec & RETex 13 & Hras ex & RETex 13 & Hras ex & RETex 13 & Hras exc & RETex 13 & Hras ex: & RETex 13 & $\begin{array}{l}\text { Negative } \\
\text { Hrasec }\end{array}$ & $\begin{array}{l}\text { Negative } \\
\text { RET ex } 13\end{array}$ \\
\hline$F$ & Hras ex 3 & RETex14 & Hras ex3 & RETex14 & Hras ex3 & RETex14 & Hras ex3 & RETex14 & Hras ex3 & RETex14 & $\begin{array}{l}\text { negasve } \\
\text { Hras ex3 }\end{array}$ & $\begin{array}{l}\text { negatve } \\
\text { RETex14 }\end{array}$ \\
\hline G & Erat & RET ex 15 & Brat & RET ex 15 & Brat & RET ex 15 & Brat & RET ex 15 & Brat & RET ex 15 & $\begin{array}{l}\text { negatvr } \\
\text { Erat }\end{array}$ & $\begin{array}{l}\text { negarve } \\
\text { REt ex } 15\end{array}$ \\
\hline $\mathrm{H}$ & & RET ex 16 & & RET ex 16 & & RET ex 16 & & RET ex 15 & & RET ex 16 & & $\begin{array}{l}\text { negasve } \\
\text { RET ex } 16\end{array}$ \\
\hline
\end{tabular}

Figure 2: Scheme of a 96-well plate to analyze five samples simultaneously. Each color corresponds to a single sample; negative controls are shown in red. 
follicular thyroid neoplasm with papillary-like nuclear features (NIFTP) was described that is treated more conservatively than classical PTC (cPTC) [19, 20]. Therefore, it is important to distinguish NIFTP and FVPTC from $\mathrm{cPTC}$ at the time of FNA. In some cases, thyroid FNAs with PTC-like cytological features, NIFTP/FVPTC can be distinguished from cPTC by a limited number of cytological features. In other cases, the cytological diagnosis of NIFTP/FVPTC can be challenging due to morphological features that overlap with those of nonneoplastic or benign follicular lesions. Since NIFTP/ FVPTC were found to be rarely positive for BRAF or RET/PTC mutations, the detection of BRAF, together with $\mathrm{RET} / \mathrm{PTC}$, may represent a robust specific test to improve the accuracy of FNA diagnosis of PTC [21].

The combination of cytology and molecular biology techniques improves the sensitivity and negative predictive value of each approach. Unfortunately, due to the limited number of samples analyzed (15) we are not able to assess the diagnostic accuracy of the molecular markers. Nevertheless, we are collecting a large number of cytological samples to define sensitivity and specificity of each analyzed marker. In any event, it is feasible that the use of a single amplification mix, instead of seven different amplification mixtures, reduces the margin of errors because it involved less sample manipulation. Figure 3 shows an example of an "indeterminate" result obtained by cytomorphology that was resolved by our molecular technique, which revealed a BRAF mutation suggestive of papillary carcinoma.

In conclusion, we describe a new rapid methodology with which to concomitantly analyze several molecular markers of thyroid disease in a single experiment with one reaction for multiplex $B R A F-R A S$, one reaction for eight exons $R E T$ gene multiplex and two reactions for RNA rearrangement. The methodology can be implemented as a fast screening analysis for the diagnosis and monitoring of cancer patients also in laboratories that do not have access to expensive equipment.

\section{MATERIALS AND METHODS}

\section{Sampling}

Ultrasound-guided fine needle aspiration of thyroid nodules was performed with a $23 \mathrm{G}$ gauge needle. The aspirated sample was used for cytology and the residual material and the needle wash were directly injected into a tube containing $1 \mathrm{ml}$ of RLT buffer (Qiagen Germantown, MD, USA) containing $10 \mu$ l beta-mercaptoethanol. The tube was stored frozen at $-80^{\circ} \mathrm{C}$ until required for DNA and RNA extraction.

\section{DNA and RNA extraction}

Nucleic acids were extracted with a QIAamp DNA mini kit and an RNeasy mini kit. After thawing a sample, RNA was extracted according to the manufacturer's instructions, but instead of discarding the eluates, these were collected and treated with absolute ethanol and stored overnight at $-20^{\circ} \mathrm{C}$. The sample was then centrifuged for 30 min. at 10,000 rpm at a low temperature and DNA was extracted using the Qiagen DNA kit procedure. There is a kit for the simultaneous extraction of nucleic acids but

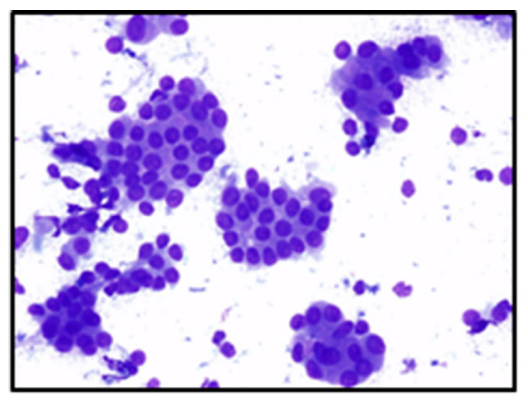

"Indeterminate" nodule

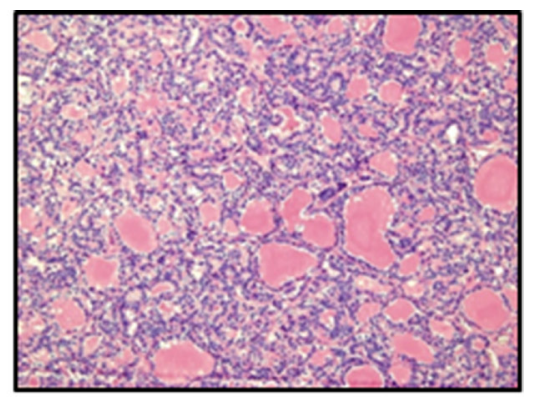

Papillary carcinoma

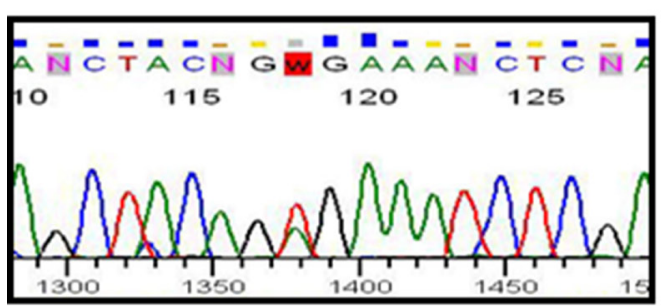

Forward sequence
BRAF

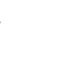


we used the separate DNA and RNA extraction Qiagen kit because it is available in our laboratory. The quantity and quality of RNA and DNA were assessed with a NanoDrop 1000 spectrophotomer (Thermo Scientific, Wilmington, DE, USA).

\section{Mutational analysis}

\section{BRAF-RAS mutations analysis by PCR multiplex and Ret mutations by PCR multiplex procedures}

To set-up our multiplex method, we used a DNA sample from peripheral blood and then we applied our methodology to study 15 FNA samples. The $B R A F, N-H-$ $K R A S$ and RET exon genes whose mutations were seen to be correlate with disease were detected by amplifications of single gene exons using the c-1000 Thermal Cycler (Bio-Rad, CA, USA). Each exon was amplified in a final volume of $50 \mu \mathrm{l}$ starting from about $100 \mathrm{ng}$ of gDNA. The amplification mixture consisted of 1X PCR buffer, $200 \mathrm{nmol}$ of dNTPs, $1 \mathrm{pmol} / \mu \mathrm{l}$ of each forward and reverse primer and $2 \mathrm{U}$ of Fast Start Taq DNA polymerase (Roche, Pleasanton, CA, USA). In this case, the PCR thermal cycle consisted of initial denaturation at $94^{\circ} \mathrm{C}$ for $10 \mathrm{~min}$, followed by 35 cycles: denaturation at $95^{\circ} \mathrm{C}$ for $30 \mathrm{sec}$, annealing at different temperatures depending on the oligonucleotide used for each region, for $30 \mathrm{sec}$, and extension at $72^{\circ} \mathrm{C}$ for $30 \mathrm{sec}$. Final extension was carried out at $72^{\circ} \mathrm{C}$ for $10 \mathrm{~min}$.

Then we selected the conditions for each amplification that would enable us to set-up two multiplex PCRs, one to amplify all the exons of $B R A F, N-H-K R A S$ genes together, and one to amplify eight exons of the $R E T$ gene. To this aim, we selected primers (Tables 2 and 3) that could all work at the same annealing temperature, and we chose each gene multiplex oligonucleotide not only according to melting temperature (to enable annealing amplification at $60^{\circ} \mathrm{C}$ ) but also based on the lengths of the amplification products, which must be well recognizable fragments. We tested many oligonucleotide pairs for each exon. In detail, we tested 5 and 6 oligonucleotides for $K R A S$ exons 2 and 3, respectively, 4 oligonucleotides for $N R A S$ exons 2 and 3, 4 oligonucleotides for $B R A F$ exon 15, and 16 oligonucleotides for $H R A S$ exons 2 and 3. Many single oligonucleotides work well in $H R A S$ amplification but not in the multiplex amplification. In addition, long stretches of HRAS exons 2 and 3 (> $600 \mathrm{bp}$ ) could not be amplified because of poor quality DNA samples. We determined the optimal multiplex concentration for each pair of oligonucleotides based on the results of many individual amplifications. The final concentration of all multiplex amplification primers for the $R E T$ gene was $1 \mathrm{pmol} / \mu \mathrm{l}$, while the multiplex $B R A F-R A S$ primer concentration was respectively $0.2 \mathrm{pmol} / \mu \mathrm{l}$ for $K R A S$, $N R A S$ and $H R A S$ exon 2, $0.4 \mathrm{pmol} / \mu \mathrm{l}$ for $B R A F$ exon 15 and $H R A S$ exon 3, $0.6 \mathrm{pmol} / \mu 1$ for $N R A S$ exon 3, and $1.2 \mathrm{pmol} / \mu \mathrm{l}$ for $K R A S$ exon 3 .
We tested five different Taq DNA polymerases that are available in our laboratory: HotMaster Taq DNA Polymerase (5 Prime, Gaithersburg, USA); AmpliTaq Gold (Thermo Fisher Scientific, Waltham, MA, USA); FastStartTaq DNA Polymerase, Expand High Fidelity PCR System and Taq DNA Polymerase (Roche), and found the best working conditions with FastStartTaq Polymerase. FastStartTaq DNA Polymerase is a thermostable, modified form of recombinant Taq DNA polymerase. It is inactive at temperatures below $75^{\circ} \mathrm{C}$, but can be activated by a 4 min $95^{\circ} \mathrm{C}$ incubation step. The combination of FastStartTaq DNA Polymerase and the dedicated PCR buffer minimizes non-specific amplification products and primer dimers. In most cases, the system easily amplifies multiple templates in a single reaction.

We also tested different concentrations of $\mathrm{MgCl}_{2}$ and found that a standard concentration $1.5 \mathrm{nM}$ was optimal. We also changed the multiplex temperature profile from that of single amplifications to enable many oligos to act simultaneously; in particular, annealing time was prolonged from $30 \mathrm{sec}$ to $1 \mathrm{~min} 30 \mathrm{sec}$, elongation time from $30 \mathrm{sec}$ to $1 \mathrm{~min}$, and the cycles were decreased from 35 to 30 .

Fine needle cytology generally results in small samples, thus we tested the smallest amount that enabled good amplification in multiplex. We used 50, 100 and $200 \mathrm{ng}$ and the best amplification was obtained with 100 ng of DNA for each amplification multiplex PCR, for a total of $200 \mathrm{ng}$. This is a very small amount of DNA compared with the 1,500 ng required for all single amplifications. We also used formalin-fixed paraffinembedded (FFPE) DNA extracted with the QIAamp@ DNA FFPE tissue kit (Qiagen) according to the supplier's recommendations to verify that our multiplex PCR worked also with nucleic acids obtained from FFPE present in archival material. In this case, more DNA was required (the optimum was about $300 \mathrm{ng}$ ). Using FFPE DNA in a 96-well plate with the thermal profiles reported for the individual amplifications, we were able to automatically analyze five different samples simultaneously. Thus, the procedure can be automated and all stages (amplification reaction, post-amplification purification sequence amplification, post-sequencing purification, dilution and sample preparation for capillary electrophoresis) can be performed on a liquid handler (Beckman Coulter BFX).

An oligonucleotide design strategy using primers bound in reverse and forward to the universal M13 sequences (M13 Fw: CGTTGTAAAACGACGGCCAGT; M13 Rev: TTTCACACAGGAAACAGCTATGAC) can simplify the method further.

All amplifications were gel controlled (2\% agarose gel in $1 \mathrm{X}$ TBE) using molecular weight marker (Fermentas Mass Ruler 100 bp ladder) with the negative controls to verify successful amplifications. Amplicon lengths ranged between 195 and 447 bp in the $B R A F-R A S$ PCR multiplex and between 176 and $447 \mathrm{bp}$ in the $R E T$ PCR multiplex. All positive PCR products were purified 
Table 2: Primers for RET point mutations

\begin{tabular}{ll}
\hline \multicolumn{1}{c}{ Gene } & \multicolumn{1}{c}{ Sequence 5' --->3' } \\
\hline RET ex5 Forward & TCGCCTGCACTGACCAAC \\
RET ex5 Reverse & TGTGCATGTGTGTAGGGTGC \\
RET ex8 Forward & TCCTTGGGCACTAGCTGGA \\
RET ex8 Reverse & GTTTCCACCGGTGCCATC \\
RET ex10 Forward & GGGCCTATGCTTGCGACACCA \\
RET ex10 Reverse & CCAGAGGGAGGGAGGGAAGTTT \\
RET ex11 Forward & ATACGCAGCCTGTACCCAGT \\
RET ex11 Reverse & CCTCGTCTGCCCAGCGTTG \\
RET ex13 Forward & AGAAGCCTCAAGCAGCATCGTC \\
RET ex13 Reverse & AGGAGCAGTAGGGAAAGGGAGAAA \\
RET ex14 Forward & TCCTGGAAGACCCAAGCT \\
RET ex14 Reverse & ATATGCACGCACCTTCATC \\
RET ex15 Forward & CTGCCATGTCACACCCTG \\
RET ex15 Reverse & GCTCCACTAATCTTCGGTATCTT \\
RET ex16 Forward & TCTCCTTTACCCCTCCTTCC \\
RET ex16 Reverse & TGTAACCTCCACCCCAAGAG \\
\hline
\end{tabular}

PCR Multiplex 1. Oligonucleotides used for the multiplex detection of the most important mutation regions of the RET gene exons: 5 (codon 338), 8 (codons 532, 533), 10 (codons 603, 609, 611, 618 and 620), 11 (codons 630, 631, 634, 635, 637 and 691), 13 (codons 768, 790 and 791), 14 (codons 804, 806, 836 and 844), 15 (codons 883, 891 and 904) and 16 (codons 912).

Table 3: Primers for point mutations in the B-RAF, $H, K$ and N-RAS genes

\begin{tabular}{|c|c|c|}
\hline Gene & Sequence 5' ---> 3' & $\begin{array}{c}\text { Work } \\
\text { concentration } \\
(\mathrm{pmol} / \mu \mathrm{l})\end{array}$ \\
\hline BRAF ex15 Forward & CTCATCCTAACACATTTCAAGCC & 0.4 \\
\hline BRAF ex15 Reverse & CTATAGTTGAGACCTTCAATGACTTTC & 0.4 \\
\hline HRAS ex2 Forward & TGGCTGAGCAGGGCCCTCCT & 0.2 \\
\hline HRAS ex2 Reverse & CTGCTGGCACCTGGACGGCGGC & 0.2 \\
\hline HRAS ex3 Forward & GGCATGAGAGGTACCAGGGAGA & 0.4 \\
\hline HRAS ex3 Reverse & AGGACAGGAGGCCCCTGCCTGGAC & 0.4 \\
\hline KRAS ex2 Forward & GGTACTGGTGGAGTATTTGATAGTG & 0.2 \\
\hline KRAS ex2 Reverse & CTGACATACTCCCAAGGAAAGTAAAG & 0.2 \\
\hline KRAS ex3 Forward & TCCCTTCTCAGGATTCCTACAGG & 1.2 \\
\hline KRAS ex3 Reverse & CCCACCTATAATGGTGAATATC & 1.2 \\
\hline NRAS ex2 Forward & AGAACCAAATGGAAGGTCAC & 0.2 \\
\hline NRAS ex2 Reverse & GTGAGAGACAGGATCAGGTC & 0.2 \\
\hline NRAS ex3 Forward & TGAGGGACAAACCAGATAGGC & 0.6 \\
\hline NRAS ex3 Reverse & CTGTAGAGGTTAATATCCGCAAATG & 0.6 \\
\hline
\end{tabular}

PCR multiplex 2: Oligonucleotides used for the multiplex detection of exon 15 of the BRAF gene, point mutations in codons 12,13 and 61 (hotspots) of the $H R A S$ gene and in codons 12,13,59, 61 of $K$-NRAS genes. The concentration primers in the mix is reported.

using the High Pure PCR Product Purification Kit (Roche) or the Gen Elute Gel Extraction Kit (Sigma-Aldrich St. Louis USA), and diluted 1:8 to optimize the sequencing conditions. Two $\mu l$ diluted samples were used in the next sequence reaction mix and sequenced on both strands (Life Technologies Big dye Terminator v3.1 Chemistry) by capillary electrophoresis performed with the Life Technologies 3730 DNA Analyzer. All sequencing reactions were performed with the same oligonucleotides used for the amplifications, except in the case of the HRAS gene in which more internal primers were used (see Table 4). 
Table 4: Primers for the sequences of HRAS exons 2 and 3

\begin{tabular}{ll}
\hline \multicolumn{1}{c}{ Gene } & \multicolumn{1}{c}{ Sequence 5' ---> 3' } \\
\hline HRAS ex2 seqForward & CTGTAGGAGGACCCCG \\
HRAS ex2 seqReverse & CGCCAGGCTCACCTCTAT \\
HRAS ex3 seqForward & ATTCCTACCGGAAGCAGGTGG \\
HRAS ex3 seqReverse & CTCACGGGGTTCACCTGTACTG \\
\hline
\end{tabular}

Table 5: Primers for the housekeeping gene GAPDH, and for RET/PTC1 and RET/PTC3 gene rearrangements

\begin{tabular}{ll}
\hline \multicolumn{1}{c}{ Gene } & \multicolumn{1}{c}{ Sequence 5' -->> $\mathbf{3}^{\prime}$} \\
\hline RET/PTC1 Forward & ATTGTCATCTCGCCGTTC \\
RET/PTC1 Reverse & CTTTCAGCATCTTCACGG \\
RET/PTC3 Forward & TGGAGAAGAGAGGCTGTATC \\
RET/PTC3 Reverse & CGTTGCCTTGACCACTTTTC \\
GAPDH Forward & CCCTTCATTGACCTCAACTACATG \\
GAPDH Reverse & TGGGATTTCCATTGATGACAAGC \\
\hline
\end{tabular}

\section{RET-PTC rearrangements}

$0.5 \mu \mathrm{g}$ of RNA was reverse transcribed into cDNA as indicated in the Qiagen "QuantiTect reverse transcription kit". The cDNA was stored at $-20^{\circ} \mathrm{C}$ until further use. The housekeeping gene GAPDH, which is uniformly expressed in all cells, was amplified by PCR to verify that the quality of the RNA samples was suitable for molecular analysis. RET-PTC rearrangements 1 and 3 were detected by PCR amplification on the c-1000 Thermal Cycler (Bio-Rad) and primer sequences (GAPDH included) are reported in Table 5. The cDNAs from the TPC-1 cell line and a PTC3 positive sample (previously typed) served as controls. PCR was performed in total volume of $25 \mu \mathrm{l}$ using $5 \mu \mathrm{l}$ of cDNA. The amplification mixture consisted of $1 \mathrm{X}$ PCR buffer (Roche), $1 \mathrm{pmol} / \mu \mathrm{l}$ of forward and reverse primers, $200 \mathrm{nmol}$ of dNTPs and $1 \mathrm{U}$ of Taq DNA polymerase (Roche). All amplifications were gel controlled (2\% agarose gel in $1 \mathrm{X}$ TBE) but only positive PCR products were purified and analyzed by direct sequencing.

\section{ACKNOWLEDGMENTS}

We thank Jean Ann Gilder (Scientific Communication srl., Naples, Italy) for revising and editing the manuscript.

\section{CONFLICTS OF INTEREST}

The authors declare no conflicts of interest.

\section{GRANT SUPPORT}

This work was partially supported by grants from the Associazione Italiana per la Ricerca sul Cancro (AIRC) IG 12962 awarded to G.C.

\section{REFERENCES}

1. Gandhi M, Evdokimova V, Nikiforov YE. Mechanisms of chromosomal rearrangements in solid tumors: the model of papillary thyroid carcinoma. Mol Cell Endocrinol. 2010; 321:36-43.

2. Sherman SI. Thyroid carcinoma. Lancet. 2003; 361:501-11.

3. Cooper DS, Dohert GM, Haugen BR, Kloos RT, Lee SL, Mandel SJ, Mazzaferri EL, McIver B, Sherman SI, Tuttle RM. American Thyroid Association Guidelines Task force Management guidelines for patients with thyroid nodules and differentiated thyroid cancer. Thyroid. 2006; 16:109-42.

4. Nikiforova MN, Nikiforov YE. Molecular diagnostics and predictors in thyroid cancer. Thyroid. 2009; 19:1351-61.

5. Nikiforov YE, Yip L, Nikiforova MN. New strategies in diagnosing cancer in thyroid nodules: impact of molecular markers. Clin Cancer Res. 2013; 19:2283-8.

6. Mehta V, Nikiforov YE, Ferris RL. Use of molecular biomarkers in FNA specimens to personalize treatment for thyroid surgery. Head Neck. 2013; 35:1499-506.

7. Ohori NP, Singhal R, Nikiforova MN, Yip L, Schoedel KE, Coyne C, McCoy KL, LeBeau SO, Hodak SP, Carty SE, Nikiforov YE. BRAF mutation detection in indeterminate thyroid cytology specimens: underlying cytologic, molecular, and pathologic characteristics of papillary thyroid carcinoma. Cancer Cytopathol. 2013; 121:197-205.

8. Musholt TJ, Fottner C, Weber MM, Eichhorn W, Pohlenz J, Musholt PB, Springer E, Schad A. Detection of papillary thyroid carcinoma by analysis of BRAF and RET/PTC1 mutations in fine-needle aspiration biopsies of thyroid nodules. World Journal of Surgery. 2013; 34:2595-2603.

9. Ciampi R, Nikiforov YE. RET/PTC rearrangements and BRAF mutations in thyroid tumorigenesis. Endocrinology. 2007; 148:936-41. 
10. Xing M. Molecular pathogenesis and mechanisms of thyroid cancer. Nat Rev Cancer. 2013; 13:184-99.

11. Soares P, Trovisco V, Rocha AS, Lima J, Castro P, Preto A, Máximo V, Botelho T, Seruca R, SobrinhoSimões M. BRAF mutations and RET/PTC rearrangements are alternative events in the etiopathogenesis of PTC. Oncogene. 2003; 22:4578-80.

12. Fattini M, Ferrario C, Bressan P, Balestra D, De Cecco L, Mondellini P, Bongarzone I, Collini P, Gariboldi M, Pilotti S, Pierotti MA, Greco A. Alternative mutations of BRAF and RET and NTRK1 are associated with similar but distinct gene expression patterns in papillary thyroid cancer. Oncogene. 2004; 23:7436-40.

13. Nikiforova MN, Lynch RA, Biddinger PW, Alexander EK, Dorn GW, Tallini G, Kroll TG, Nikiforov YE. RASPoint Mutations and PAX8-PPARg Rearrangement in Thyroid Tumors: Evidence for Distinct Molecular Pathways in Thyroid Follicular Carcinoma. J Clin Endocrinol Metab. 2003; 88:2318-2326.

14. Eng C, Mulligan LM, Healey CS, Houghton C, Frilling A, Raue F, Thomas GA, Ponder BA. Heterogeneous mutation of the RET proto-oncogene in subpopulations of medullary thyroid carcinoma. Cancer Res. 1996; 56:2167-70.

15. Romei C, Cosci B, Renzini G, Bottici V, Molinaro E, Agate L, Passannanti P, Viola D, Biagini A, Basolo F, Ugolini C, Materazzi G, Pinchera A, et al. RET genetic screening of sporadic medullary thyroid cancer (MTC) allows the preclinical diagnosis of unsuspected gene carriers and the identification of a relevant percentage of hidden familial MTC (FMTC). Clin Endocrinol (Oxf). 2011; 74: 241-247.

16. Haugen BR, Alexander EK, Bible KC, Doherty GM, Mandel SJ, Nikiforov YE, Pacini F, Randolph GW, Sawka AM, Schlumberger M, Schuff KG, Sherman SI, Sosa
JA, et al. American Thyroid Association Management Guidelines for Adult Patients with Thyroid Nodules and Differentiated Thyroid Cancer: The American Thyroid Association Guidelines Task Force on Thyroid Nodules and Differentiated Thyroid Cancer. Thyroid. 2016; 26:1-133.

17. Nardi F, Basolo F, Crescenzi A, Fadda G, Frasoldati A, Orlandi F, Palombini L, Papini E, Zini M, Pontecorvi A, Vitti P. Italian consensus for the classification and reporting of thyroid cytology. J Endocrinol Invest. 2014; 37: 593-9.

18. Ferris RL, Baloch Z, Bernet V, Chen A, Fahey TJ 3rd, Ganly I, Hodak SP, Kebebew E, Patel KN, Shaha A, Steward DL, Tufano RP, Wiseman SM, et al. American Thyroid Association Surgical Affairs Committee. American Thyroid Association Statement on Surgical Application of Molecular Profiling for Thyroid Nodules: Current Impact on Perioperative Decision Making. Thyroid. 2015; 25: 760-8.

19. Nikiforov YE, Seethala RR, Tallini G, Baloch ZW, Basolo F, Thompson LD, Barletta JA, Wenig BM, Al Ghuzlan A, Kakudo K, Giordano TJ, Alves VA, Khanafshar E, et al. Nomenclature Revision for Encapsulated Follicular Variant of Papillary Thyroid Carcinoma: A Paradigm Shift to Reduce Overtreatment of Indolent Tumors. JAMA Oncol. 2016; 2:1023-9.

20. Tallini G, Tuttle RM, Ghossein RA. The history of the follicular variant of papillary thyroid carcinoma. J Clin Endocrinol Metab. 2016; 102:15-22.

21. Strickland KC, Vivero M, Jo VY, Lowe AC, Hollowell M, Qian X, Wieczorek TJ, French CA, Teot LA, Sadow PM, Alexander EK, Cibas ES, Barletta JA, et al. Preoperative Cytologic Diagnosis of Noninvasive Follicular Thyroid Neoplasm with Papillary-Like Nuclear Features: A Prospective Analysis. Thyroid. 2016; 26:1466-1471. 